\title{
Acute intermittent porphyria after gastroplasty
}

\author{
Alzira Alves Siqueira Carvalho', Daniella Dias Arçari²
}

A 28-year-old female underwent gastroplasty for obesity in an uneventful procedure. This was followed within five days by persistent abdominal pain associated with weakness that progressed to generalized flaccid quadriparesis. She developed respiratory distress, and required intubation. Cerebrospinal fluid (CSF) revealed a normal cell count and elevated total protein. Her folate and vitamin B12 levels were normal. Electromyography (EMG) and nerve-conduction studies (NCS) showed acute generalized motor-sensory demyelinating neuropathy predominantly in the lower limbs. A diagnosis of Guillain-Barré syndrome was made, and a five-day course of immunoglobulin was begun, which did not produce any improvement.

Three months later, she still had not improved and she came into our service looking for a diagnosis.

The patient reported that seven relatives had lower limb weakness, and that five of them died due to respiratory failure after the onset of neurological manifestations. Neurological examination showed moderate quadriparesis, with proximal weakness greater than distal weakness. Muscle reflexes were absent, and no pathological reflexes were demonstrated. The patient's sense of feeling was normal.

The blood tests were normal. We repeated the EMG and NCS, which showed pure motor axonal polyradiculoneuropathy.

The porphobilinogen (PBG) and $\delta$-aminolevulinic acid (ALA) levels in urine were high: $32.4 \mathrm{mg} / 24 \mathrm{~h}$ (normal range: $0-2 \mathrm{mg} / 24 \mathrm{~h}$ ) and $26.2 \mathrm{mg} / \mathrm{g}$, (normal value: $4.5 \mathrm{mg} / \mathrm{g}$ ) respectively, thus indicating the diagnosis of acute intermittent porphyria.

Six months later, the patient returned complaining of a burning feeling in her lower abdomen and upper limbs. Two days after this, she became weak again and developed quadriparesis. She was then treated with intravenous glucose (300 g per day), with a slight improvement. Hematin was not used because it was not available at our service.

Because the patient's condition continued to worsen, we decided to reverse the gastric bypass, given that this could decrease the risk of further attacks. Within a couple days, she got better and her muscle strength gradually improved.

\section{DISCUSSION}

The case reported above is important because it provides the description of a porphyria crisis subsequent to bariatric surgery in a patient without any previous medical history. The first acute episode was triggered by gas- troplasty, and recurrence of the attack was probably due to the persistent nutritional disorder caused by surgery. The low-calorie diet $(600 \mathrm{kcal} /$ day $)$ that the patient had been following since the gastroplasty could have been the precipitating factor for the second crisis.

With regard to correlations between polyneuropathy and gastroplasty, Abarbanel et al. studied 500 patients with gastroplasty but only 16 (3.2\%) were identified as presenting polyneuropathy ${ }^{1}$. Thaisetthawatkul et al found that 71 patients $(16 \%)$ presented polyneuropathy out of 435 patients who underwent bariatric surgery. Such cases of neuropathy have multifactorial causes, but malnutrition may be the most important risk factor ${ }^{2}$. Reduced calorie intake in patients with acute intermittent porphyria is associated with increased excretion of ALA and $\mathrm{PBG}^{3,4}$. Moreover, reduced glucose levels are an important precipitant because glucose inhibits ALA synthase.

Gastroplasty has been reported to be the trigger for a porphyria crisis in two cases ${ }^{4,5}$. In one case, Hebert et al. described a 57-year-old woman with abdominal pain and weakness that progressed to flaccid quadriparesis ${ }^{4}$. In the other case, Daniela et al, described a 31-year-old woman with abdominal pain, nausea and vomiting that were presented two weeks after gastroplasty ${ }^{5}$. In the first case, reversal of the gastroplasty was the treatment implemented. The second patient showed progressive improvement over an eight-month period, without the need for reversal of the surgery.

\section{REFERENCES}

1. Abarbanel JM, Bergner VM, Simian A, Solomon H, Charity I. Neurologic complications after gastric restriction surgery for morbid obesity. Neurology 1987;37:196-200.

2. Thaisetthawatkul P, Collazo-Clavell ML, Sarr MG, Norell JE, Dyck PJB. A controlled study of peripheral neuropathy after bariatric surgery. Neurology 2004;63:1462-1470.

3. Albers JW, Fink JK. Porphyric Neuropathy. Muscle Nerve 2004;30:410-422.

4. Bonkovsky HL, Siao P, Roig Z, Hedley-Whyte ET, Flotte TJ. Case 20-2008: a 57-year-old woman with abdominal pain and weakness after gastric bypass surgery. N Engl J Med 2008;358:2813-2825.

5. Lopes DVA, Valle MA, Taguti J, Taguti RCTC, Betônico GN, Medeiros FC. Porfiria aguda intermitente: relato de caso e revisão da literatura. Rev Bras Ter Intensiva 2008;20:429-434.

\section{PORFIRIA AGUDA INTERMITENTE APÓS GASTROPLASTIA}

Discipline of Neurology, ABC Foundation Medical School, Santo André SP, Brazil: ${ }^{1} \mathrm{PhD}$ in Neurology and In Charge of the Neuromuscular Diseases Sector; ${ }^{2}$ Resident Physician in Neurology at the Service.

Correspondence: Alzira Alves de Siqueira Carvalho - Rua lara 122/62 - 04542030 São Paulo SP - Brasil. E-mail: alzira@myogenetica.com.br

Received 14 May 2011. Received in final form 29 July 2011. Accepted 5 August 2011. 